\title{
INCIDENCE OF POSTURAL CHANGES AND TEMPOROMANDIBULAR DISORDERS IN STUDENTS
}

\section{INCIDÊNCIA DAS ALTERAÇÕES POSTURAIS E TRANSTORNOS TEMPOROMANDIBULARES EM ESTUDANTES}

\author{
Paulo de Jesus Chaves ${ }^{1,2}$, Franceane Esther Moreira de Oliveira ${ }^{2}$, Laila Cristina Moreira Damázio \\ 1. Instituto de Ensino Superior Presidente Tancredo Neves, São João Del Rei, MG, Brazil. \\ 2. Universidade Federal de São João Del Rei, São João Del Rei, MG, Brazil.
}

\section{ABSTRACT}

Objective: The aim of this study was to identify the incidence of postural changes and temporomandibular disorders (TMD) in children and adolescents. Methods: We selected 117 individuals aged 10-18 years from a state school in the Zona da Mata region of Minas Gerais. The students were evaluated in four stages: assessment of body weight and height and calculation of body mass index; posture evaluation using a questionnaire developed by the researchers; application of a questionnaire recommended by the American Academy of Orofacial Pain to assess TMD; and, finally, application of the Fonseca anamnesis questionnaire. Results: Of our sample, $26.36 \%$ had no TMD, 50.9\% had mild TMD, 21.8\% moderate TMD, and $0.9 \%$ severe TMD. Of the participants with moderate or severe TMD (30.8\%), about 56\% had some kind of change in head positioning. We found that $88 \%$ of the children with moderate or severe TMD had changes in the shoulders. Conclusion: The postural changes found in the head and shoulders are related to the biomechanical adaptation of the muscles of mastication and consequent changes in the TMJ. Level Of Evidence Iii, Non-Consecutive Patient Study Without Gold Reference Standard Applied Uniformly.

Keywords: Temporomandibular joint disorders. Physical therapy specialty. Therapy.

\section{RESUMO}

Objetivo: O objetivo deste estudo foi identificar a incidência de alterações posturais e transtornos temporomandibulares (TTM) em crianças e adolescentes. Métodos: Foram selecionados 117 indivíduos com idade entre 10 e 18 anos, de uma escola estadual na Zona da Mata de Minas Gerais. A avaliação dos escolares foi feita em quatro etapas: avaliação do peso corporal, da estatura e cálculo do índice de massa corporal; avaliação postural, utilizando um questionário elaborado pelos pesquisadores; aplicação do questionário para avaliação de TTM recomendado pela American Academy of Orofacial Pain; e, por fim, aplicação do questionário anamnésico de Fonseca. Resultados: Em nossa amostra, 26,36\% não tinham TTM, 50,9\% apresentavam TTM leve, 21,8\% TTM moderado e 0,9\% TTM severo. Dos participantes com TTM moderado ou severo $(30,8 \%)$, cerca de $56 \%$ apresentaram algum tipo de alteração de posicionamento da cabeça. Constatou-se que $88 \%$ das crianças com TTM moderado ou severo tinham alterações nos ombros. Conclusão: As alterações posturais verificadas na cabeça e nos ombros estão relacionadas com a adaptação biomecânica dos músculos da mastigação e a consequente alteração na ATM. Nível De Evidência lii, Estudo De Paciente Não Consecutivo Sem Padrão De Referência Ouro Aplicado Uniformemente.

Descritores: Transtornos da articulação temporomandibular. Fisioterapia. Terapia.

Citation: Chaves PJ, Oliveira FEM, Damázio LCM. Incidence of postural changes and temporomandibular disorders in students. Acta Ortop Bras. [online]. 2017;25(4):000-00. Available from URL: http://www.scielo.br/aob.

\section{INTRODUCTION}

The temporomandibular joint (TMJ) is a modified ginglimal joint composed of the condylar process, fossa of the mandible and articular tubercle of the temporal bone.-18 This joint allows the protrusion, elevation, retraction and lateral sliding movements of the mandible, which are mainly produced by mastication muscles: masseter, temporal and lateral and medial pterygoid. ${ }^{2-18}$ There are diseases that compromise TMJ and adjacent structures, constituting temporomandibular disorders (TMD), which are characterized by pain, joint sounds, chewing and speech impairments, irregular jaw function and even changes in global posture. ${ }^{3}$

A ATM is directly related to the biomechanics of the cervical and scapular structures through a common neuromuscular system, being that postural alterations of the spine May entail to disturbances in the TMJ and vice versa. Body realignment may interfere with the function and organization of the joint, Just as it can be consequence of temporomandibular disorder. ${ }^{4}$ This relationship of reciprocity between body posture and TMD can establish a form of prevention and rehabilitation for patients. ${ }^{3}$

All authors declare no potential conflict of interest related to this article. 
Studies show that about $40 \%$ of the world population has some type of TMD and several studies indicate what carriers with such dysfunction can undergo several changes in the positioning of the head and shoulders. In addition, It is verified in the literature there is a greater impairment of $\mathrm{TMJ}$ in women than in men, in a ratio of 4 to 1 , respectively. ${ }^{5}$

The etiology of TMD is related to muscular hyperactivity and this, in turn, has as its main cause the practice of parafunctional habits that is aggravated by emotional stress. The symptoms of TMD are: pain, headache, joint noise, besides changes in mandibular dynamics, restriction of movements and changes in muscle tone. ${ }^{4}$ Individuals with TMD present an overload in the cervical muscles due to increased activity of the masticatory muscles to compensate for joint disorder. ${ }^{6}$ Such overloading may result in mandibular and spinal deviations, as well as cervical hyperlordosis, since there is shoulder elevation and head protrusion in patients with TMD. Thus, although the main complaint of TMD is the pain and limitation of the mandibular opening, this may be accompanied by muscle fatigue and alteration in the bone axis of the spine and, therefore, postural problems in the patient. ${ }^{7}$ The objective of this article was to identify the incidence of postural changes and TMD in school children and adolescents in a medium-sized city in the forest area of Minas Gerais.

\section{METHODS}

Were selected 117 school - aged individuals aged 10 to 18 years old were selected from a state school of Minas Gerais. As inclusion criterion were school children and adolescents between the ages of 10 and 18, of both genders, who signed the term of free and informed consent and accepted to participate in the research. The exclusion criterion was children and adolescents who did not agree to participate in the study and did not sign the free and informed consent form.

All the participants were informed about the questionnaire to be answered, the TMD assessment, the postural evaluation and their responsible signed the consent form and free and informed consent at the time of admission to the research, according to Council Resolution 466/2004 The development of this research project was approved by the Ethics Committee of the Federal University of São João Del Rei / Santo Antônio Campus (protocol 017/2014). The evaluation of the students in the research followed four stages: in the first stage the body weight, height and calculation of Body Mass Index (BMI) were evaluated; In the second stage, a postural evaluation was performed, using a questionnaire prepared by the researchers. In the third stage, the questionnaire for the evaluation of TMD recommended by the American Academy of Orofacial Pain was applied, and in the fourth step the Fonseca anamnestic questionnaire was applied, being that Fonseca anamnestic questionnaire was applied only to the individuals who answered "yes" "On the questionnaire of the American Academy of Orofacial Pain. The postural changes were evaluated through the application of a postural evaluation sheet prepared by the researchers, being that and the same was done in a calm environment where the child or adolescent was evaluated in three positions: anterior, profile and posterior. The postural evaluation was performed with the supervision of a physiotherapist.

The American Academy of Orofacial Pain Questionnaire was used for an initial screening of potential TMD patients. This questionnaire presents ten TMD questions. The questions are simple questions that can be answered by the student, having as answer: yes or no. ${ }^{10-17}$ The Fonseca anamnestic questionnaire was applied in the last phase and aims to characterize the severity of TMD, ${ }^{11-19}$ and is widely used in epidemiological studies. This questionnaire consists of ten simple questions, where each question has three possible answers (yes, no and sometimes), for which the scores are: 10, 5 and 0, respectively. The final sum of the questionnaire allows to classify the evaluated according to the severity of the symptoms: without TMD (0 to 15 points), mild TMD (20 to 45 points) and moderate TMD (50 to 65) and severe TMD (70 to 100 points ).

\section{RESULTS}

The results showed that of the 110 individuals evaluated, the mean age was 13.9 years (10-18) and the mean BMI was $19.3 \mathrm{~kg} / \mathrm{cm}$. About 18 individuals were not evaluated by the Fonseca (NA) questionnaire because they answered "no" in all questions from the American Academy of Orofacial Pain Questionnaire. Among the total of the sample, about $10 \%$ of the individuals $(n=11)$ had no TMD, 50.9\% ( $n=57)$ had mild TMD, 21.8\% $(n=24)$ had moderate TMD and $0.9 \%(\mathrm{~N}=1)$ presented severe TMD, as shown in Figure1. Of the $22.7 \%(n=25)$ who had moderate or severe TMD, about $56 \%$ $(n=14)$ presented some type of head alteration and the other $44 \%$ $(n=11)$ presented no head position changes. Among the postural alterations evaluated in the head was observed that $12 \%$ presented head protrusion and $44 \%$ presented head tilt to the right or left. Among the patients with moderate or severe TMD, 22.7\% $(n=25)$, $64 \%$ presented a shoulder elevation and $24 \%$ had a shoulder protrusion. Other postural alterations were observed in the studied population, and $67.27 \%(\mathrm{n}=74)$ had pelvic alterations, such as anteversion and pelvic retroversion, and $24.3 \%(n=18)$ of these individuals were classified as having moderate and severe TMD. Other postural alterations were found, such as: cervical hyperlordosis, thoracic hyperkinesis, lumbar hyperlordosis and thoracolumbar scoliosis, with about 24.1 ( $n=14)$ presenting moderate and severe TMD. In the knee, changes were identified as: valgus knee, varus knee and recurvatum knee in $26 \%(n=13)$ of individuals with moderate and severe TMD.

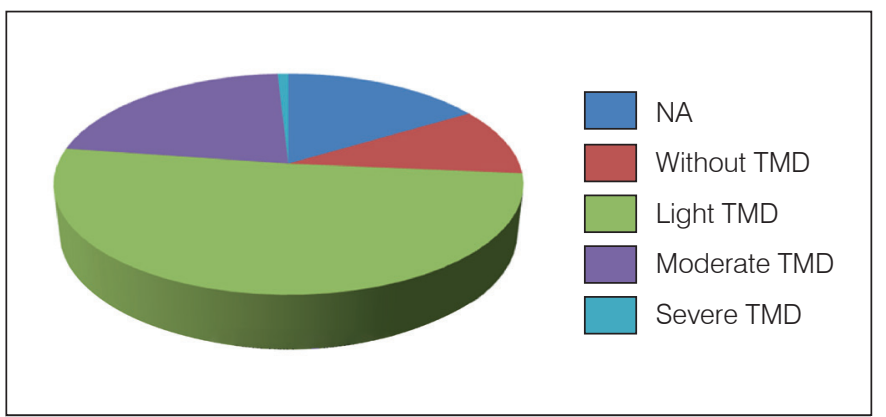

Figure 1. TMD Severity by Fonseca's Anamnestic Questionnaire. The questionnaire presented the following items:no reply (NA), without TMD, mild TMD, moderate TMD and severe TMD.

\section{DISCUSSION}

Thus, a high incidence of postural changes and TMD can be observed in the studied population. The higher incidence of alterations in the cervical, head and shoulders region is related to the mechanism of biomechanical adaptation of chewing muscles in this region. ${ }^{12-20}$ DTM promotes compensatory mechanisms of the masticatory muscles that fixate in the region of the sternum and the scapula..$^{13}$ This biomechanical adaptation pulls the shoulder superiorly or anteriorly, determining changes in the shoulders. ${ }^{8}$ In the present study, no correlation was found between postural changes found in the spine, hip and lower limbs with the presence of $\mathrm{TMD}$, but these alterations could trigger future problems in the study population. These changes may be related to the intrinsic 
and extrinsic factors of the child or adolescent. ${ }^{14}$ Studies show that there are genetic, ergonomic and lifestyle factors that may trigger these postural changes. ${ }^{15}$ With this, it becomes necessary to develop orientation programs And rehabilitation for these children and adolescents with the purpose of preventing future complications. ${ }^{16}$

\section{CONCLUSION}

It was concluded that a high incidence of mild TMD and postural alterations occurred in the head, neck and shoulders region among the evaluated children and adolescents. There was no significant relationship between pelvic and knee changes, as well as BMI, and the occurrence of TMD. Thus, a program of prevention and orientation of these students is essential, aiming at reducing the incidence of postural changes and consequently TMD.

\section{ACKNOWLEDGEMENTS}

We thank the pedagogical team of the State School of a city of Minas Gerais, the school board and the teacher of Physical Education. In addition, we thank the students and parents who accepted the participation in the research.

AUTHORS' CONTRIBUTIONS: Each author made significant individual contributions to this manuscript. LCMD (0000-0001-7370-8692)* and PJC (0000$0002-4645-867 X)^{\star}$ were the main contributors in drafting the manuscript. FEMO (0000-0002-9587-3167)* and PJC evaluated the data from the statistical analysis. LCMD, PJC, and FEMO conducted the bibliographic research, revised the manuscript, and contributed to the intellectual concept of the study. *ORCID (Open Researcher and Contributor ID).

\section{REFERENCES}

1. Salvador EM. Ribeiro F, Previlatto R. Fisioterapia nas disfunções temporomandibulare [monografia]. Lins, SP: Centro Universitário Católico de Lins; 2006.

2. Moore KL. Anatomia orientada para a clínica. 6a. ed. Rio de Janeiro: Guanabara Koogan; 2010

3. Azato FK, Castillo DB, Coelho TMK, Taciro C, Pereira PZ, Zomerfeld Z, et al. Influência do tratamento das desordens temporomandibulares na dor e na postura global. Rev Dor, São Paulo. 2013;14(4):280-3.

4. Anequini A, Cremonez AA. Disfunção da articulação temporomandibular [monografia]. Lins, SP: Centro Universitário Católico de Lins; 2009.

5. Donarumma MD, Muzilli CA, Ferreira C, Nemr K. Disfunções temporomandibulares: sinais, sintomas e abordagem multidisciplinar. Rev CEFAC. 2010;12(5):788-94

6. Barcelos E. Efeitos dos exercícios terapêuticos na disfunção temporomandibular: estudo de caso [monografia] Tubarão: Universidade do Sul de Santa Catarina; 2008

7. Ferreira FV, Ferreira FV. Peroni AB, Tabarelli Z. Desordens temporomandibulares: uma abordagem fisioterapêutica e odontológica. Stomatos. 2009;15(28):27-37.

8. Conti PBM, Sakano E, Ribeiro AGO, Schivinski CIS, Ribeiro JD. Avaliação da postura corporal em crianças e adolescentes respiradores orais. J Pediatr. (Rio J). 2011;87(4):357-63

9. Kinote AP, Monteiro LT, Vieira AA, Ferreira NM, Vasconcellos AP. Perfil funciona de pacientes com disfunção temporomandibular em tratamento fisioterápico. Rev Bras Promoção Saúde, Fortaleza, 2011;24(4):306-12.

10. Okeson JP. Dor orofacial: guia de avaliação, diagnóstico e tratamento. São Paulo: Quintessence; 1998

11. Fonseca DM, Bonfate G, Valle AL, Freitas SFT. Diagnóstico pela anamnese da disfunção craniomandibular. RGO (Porto Alegre);1994;42(1):23-4
12. Carrara SV, Conti PCR, Barbosa JS. Termo do 1ำ consenso em disfunção temporomandibular e dor orofacial. Dental Press J Orthod. 2010;15(3):114-20.

13. Souza JA. Postura e disfunção temporomandibular: avaliação fotogramétrica baropodométrica e eletromiográfica [dissertação]. Santa Maria: Universidade Federal de Santa Maria; 2010.

14. Santos TS, Piva MR, Ribeiro MH, Antunes AA, Melo AR, Silva ED. Lasertherapyefficacy in temporomandibular disorders: control study. Braz J Otorhinolaryngol. 2010;76(3):294-9.

15. Diniz MR, Sabadin PA, Leite FP, Kamizaki R. Psychological factors related totemporomandibular disorders: an evaluation of students preparing for college entrance examinations. Acta Odontol Latinoam. 2012;25(1):74-81.

16. Weber P, Corrêa EC, Ferreira FS, Soares JC, Bolzan GP, Silva AM.Cervical spine dysfunction signs and symptoms in individuals withtemporomandibular disorder. J Soc Bras Fonoaudiol. 2012;24(2):134-9.

17. Chaves TC, Oliveira AS, Grossi DB. Principais instrumentos para avaliação da disfunção temporomandibular, parte I: índices e questionários; uma contribuição para a prática clínica e de pesquisa. Fisioter Pesquisa. 2008;15(1):92-100. 1.

18. Drake RL, Vogl AW, Mitchell AWM. Gray's: anatomia clínica para estudantes. $2^{a}$ ed. Rio de Janeiro: Elsevier; 2010.

19. Manfredi APS, Silva AA, Vendite LL. Avaliação da sensibilidade do questionário de triagem para dor orofacial e desordens temporomandibulares recomendado pela Academia Americana de Dor Orofacial. . Rev Bras Otorrinolaringol. 2001;67(6):763-8.

20. Vinholi GH, Coelho TM, Silva AL, Insaurralde E, Mazzini CL, Terra GA. Frequência da postura anterior da cabeça em indivíduos com disfunção temporomandibular. Rev ABO-MI. 2009;26(2):111-5. 